\title{
Література:
}

1. Brown Dan. The Da Vinci Code / D. Brown. London: Bentam Press Corgi, 2003. $605 \mathrm{p}$.

2. Poe E.A. The Oval Portrait / E.A. Poe. //Prose and Poetry. M.: Paduga Publishers, 1983. P. 209 - 213.

DOI https://doi.org/10.30525/978-9934-26-180-0-20

\section{THE CHARACTERISTIC FEATURES OF THE CREOLIZED HUMOROUS TEXT (FUNCTIONAL ASPECT)}

\author{
Kuznietsova O. V. \\ Candidate of Philological Sciences, \\ Associate Professor at the Department of English Philology \\ V. N. Karazin Kharkiv National University \\ Kharkiv, Ukraine
}

The concept of «text» is in constant advancement, caused by the technical progress of society. The development of creolized texts has become a product of intensive use of visual elements in modern communication. The creolized text «is characterized by pragmatic capacity and a variety of linguistic and graphic means that make up its structure» [2, p. 150]. Such texts consist of two inhomogeneous parts - verbal and nonverbal. These parts form a visual, structural, semantic and functional unit. Their aim is to influence the addressee in an integrated manner. Non-verbal means, accompanying the written language, expand the semantic content of the text, adding new elements to its meaning.

In our view, attention should be paid to the functional purpose of the creolized text. According to M. N. Kozhina, «in the process of functioning the richest creative possibilities of language are manifested, which are fixed in speech works, in texts, but never exhaust themselves due to the infinite variety of extralinguistic situations and factors (in their combinations) that determine the laws of the language functioning» [1, p. 17].

Since this work is devoted to the analysis of the creolized humorous text, we consider it most appropriate to rely on the classification of functions of the humorous text by V. O. Samokhina. According to her classification, humorous texts can perform such functions as factual / contact-establishing, switching, attractive, language-creating, critical and detabooing [3, p. 19-20]. As a 
creolized humorous text, we consider caricature, which is aimed at performing a wide range of functions in communication. Among the key functions of a caricature we distinguish attractive, critical and detabooing functions.

The primary task of a humorous caricature is to attract the addressee's attention to its creolized organization. To entertain the addressee and draw his attention authors use different stylistic devices. For example:

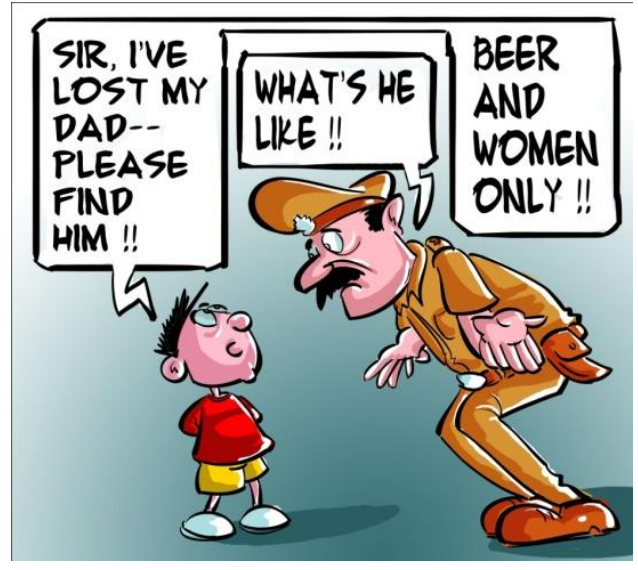

Fig. 1. Attractive function

The non-verbal component is expressed by images of a boy and a policeman, as well as capital letters in bold. All this emphasizes the importance of the situation - the boy got lost. Comic effect arises due to the verbal component, which violates the logical and conceptual norm, expressed by the homonymy of the word like. This is how the pun appears: «What's he like?», in which like is a preposition, was perceived by the boy as «What does he like?», where like would be a verb. Accordingly, instead of describing his father's appearance, the boy talked about his preferences.

The next function is critical, which is to criticize the social, political, cultural, aesthetic norms of society by means of comic. The next example presents a comic precedent situation of the man's selectivity of tasks. The critical function is represented by mocking of social norms - a wife is too authoritarian in relation to her husband. 


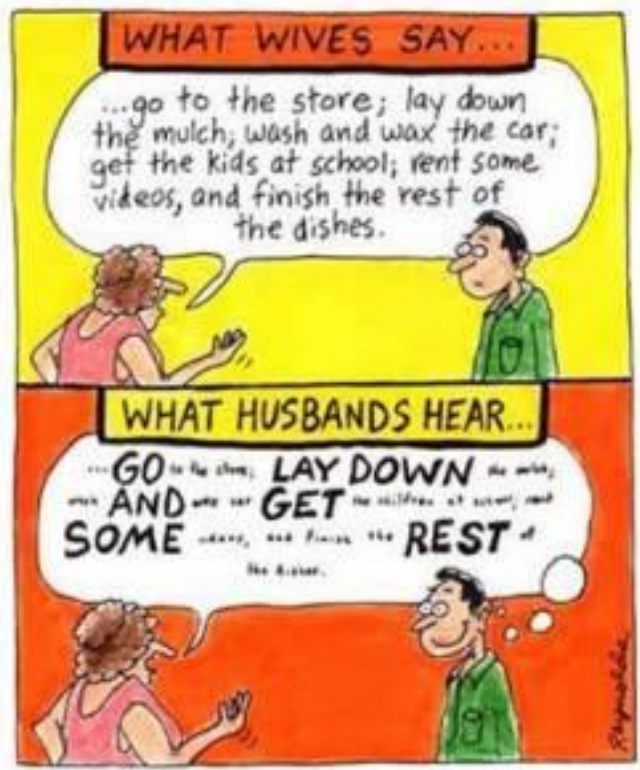

Fig. 2. Critical function

The non-verbal component is expressed by colour - red emphasizes the words and expressions that are important for the perception of the man. The comic effect of the verbal component lies in the game with fonts - important information for the man is depicted in capital letters in bold, and unimportant with a very small font that cannot be read. Laziness and indifference to household chores, often attributed to men, are exaggerated due to the bold type. The man rejected everything superfluous, except for the verbs important to him (GO ... LAY DOWN ... AND ... GET ... SOME ... REST). Also comical is the expression on the husband's face, namely his reaction to his wife's instructtions - rejecting «extra» information in his understanding, the husband rejoiced and focused on what was important.

The detabooing function covers such forbidden for public communication topics as death, sex, drugs, religion. The essence of this function lies in the usage of obscene language, Americanism, slang and more.

Another example reveals the theme of religious criticism. It is based on the principle of parallelism. Non-verbal component depicts two women who represent European and Muslim cultures. The verbal - two sentences with parallel constructions (Everything covered but her eyes, what a cruel male- 
dominated culture; Nothing covered but her eyes, what a cruel male-dominated culture) in which humor lies in pronouns «everything» and «nothing». In fact, criticism is directed at men whose preferences in a particular culture are a priority - women are willing to do anything to please them.

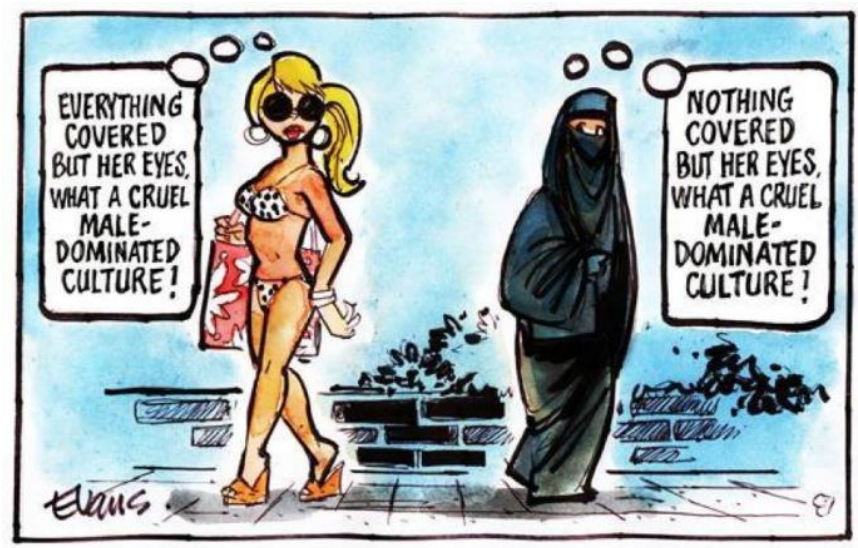

Fig. 3. Detabooing function

Thus, creolization is such an element of the text, without which the text loses its cognitive essence, that is, its textuality. Humorous caricatures as a type of the creolized text perform attractive, critical and detabooing functions. Their aim is to influence the addressee and to provoke emotional reaction of laughter.

\section{Література:}

1. Кожина М. Н. Стилистика русского языка. Изд. 4-е. Москва : Флинта : Наука, 2008. 464 с.

2. Кузнєцова О. В. Постмодерністський комічний ідіодискурс Дейва Баррі: дис. ... канд. філол. наук : 10.02.04. Харків, 2019. 241 с.

3. Самохіна В. О. Жарт у сучасному комунікативному просторі Великої Британії та США: монографія. Вид. 2-е. Харків : ХНУ імені В. Н. Каразіна, 2012. 360 с.

\section{Джерела ілюстративного матеріалу:}

1. 9 GAG: Go Fun The World. URL: https://9gag.com/gag/2048642

2. Ezibota. URL: https://ezibota.tumblr.com/post/38083963363/everythingcovered-but-her-eyes-what-a-cruel

3. Steemit. URL:www.steemit.com/art/@fadime/caricature-art 